\title{
THE ROLE OF SOME CYTOKINES IN ECTOPIC PREGNANCY
}

\section{IN IRAQ-THIQAR}

\section{THAMER JABER CHALI \& NADHAMKADHAM MAHDI}

Department of Microbiology College of Medicine, University of Basrah, Basrah, Iraq

\section{ABSTRACT}

This study aimed to investigate the effected of cytokines IL1RA, IL2,IL-6,IL8, TNF a and INF a on the ectopic pregnant women.

A case-controls study conducted in the Department of Obstructive and Gynecology/Bent al Huda Hospital in IRAQ - THI-Qar governorate from April 2017 to October 2017.

Ninety individuals involved in the current study, 50 women with an ectopic pregnancy in the first trimester and 40 health pregnant women in the first trimester as controls were enrolled in this study.

Out of 50 ectopic pregnancy 23 have a risk factor. The highest percentage was showed in those with a pelvic inflammatory disease which was (43.5\%), followed by the intrauterine contraceptive device (17.3\%) while the smoking was lowest with the percentage of $(4.3 \%)$.

The most frequency age group for ectopic pregnancy was shown in (25-34) years (42\%), followed by (35-45 years) $38 \%$. while (15-24) years showed the lowest percentage (20\%).

The mean concentration level of serum interleukinsIL1RA, IL2, IL6, IL8, TNFa, INFa were measured in ectopic pregnancy and controls group.

IL1RA, IL6, IL8, TNF, INF a serum concentration was higher in ectopic pregnancy than controls group.

Mean $\pm S D$ Serum concentration levels of IL1RA for ectopic pregnancy and controls group were $(9.3375 \pm 3.260 \mathrm{ng} / \mathrm{ml}),(2.1151 \pm 1.16 \mathrm{ng} / \mathrm{ml})$ respectively and this difference was highly significant $(P$ value 0.00$)$, while IL2 concentration Mean $\pm S D$ in ectopic pregnancy was $(2.2582 \pm 1.224 \mathrm{ng} / \mathrm{ml})$ and control group was $(4.9923 \pm 1.59 \mathrm{ng} / \mathrm{ml})$ $(P<0.05)$ with no statistically significance, Serum concentration level of IL6 for ectopic pregnancy was $(23.2508 \pm 7.18$ $\mathrm{Pg} / \mathrm{ml})$ while controls group was $(9.0025 \pm 2.74 \mathrm{Pg} / \mathrm{ml})$ with statistically significant differences (P value 0.00), IL8 level in ectopic pregnancy and controls show $(76.9892 \pm 19.8 \mathrm{Pg} / \mathrm{ml}),(26.5498 \pm 11.85 \mathrm{Pg} / \mathrm{ml})$ respectively and this different were statistically significant (P value 0.00).

Serum concentration levels of TNF a for ectopic pregnancy and controls group were $(31.5328 \pm 10.22 \mathrm{Pg} / \mathrm{ml})$, $(9.5346 \pm 10.22 \mathrm{Pg} / \mathrm{ml})$ respectively this different was statistic significant (P value 0.00).

Serum concentration levels of INF a for ectopic pregnancy were $(24.7813 \pm 7.60 \mathrm{Pg} / \mathrm{ml})$ while the control group were $(8.2140 \pm 2.68 \mathrm{Pg} / \mathrm{ml})$ this different was statistic significant (P value 0.00)

The mean concentration of cytokines for different age groups show IL IRA 
Were highly (Mean \pm SD10.91 $\pm 3.08 \mathrm{ng} / \mathrm{ml}$ ) in age group (35 - 45 year), IL 2 were highly (Mean $\pm S D 2.26 \pm 0.932 \mathrm{ng} / \mathrm{ml})$ in age group (35 - 45 year). IL 6 were highly (Mean $\pm S D 27.021 \pm 7.628 \mathrm{Pg} / \mathrm{ml})$ in the age group (15 - 24 years). IL 8 were highly $(M e a n \pm S D 82.912 \pm 15.21 \mathrm{Pg} / \mathrm{ml})$ in the age group $(25$ - 34 year). TNFa were highly (Mean \pm SD36.09 $\pm 9.405 \mathrm{Pg} / \mathrm{ml})$ in the age group (25 - 34 year) and INF $\alpha$ were highly (Mean $\pm S D 26.147 \pm 5.50 \mathrm{Pg} / \mathrm{ml})$ in the age group (35 - 45 years). KEYWORDS: Gynecology, Serum, Pelvic Inflammatory Disease, ILIRA, IL6, IL8, TNF a \& INF a

Received: Jun 18, 2018; Accepted: Jul 09, 2018; Published: Jul 28, 2018; Paper Id.: IJMPSAUG20185

\section{INTRODUCTION}

Ectopic pregnancy EP is a fertilized egg when implantation outside of the endometrial cavity (Walker et al. 2007). Global Incidence of ectopic pregnancy increases between 1970 and 1992 (Chang et al. 2003). It was different from region to region with the same geographical conditions and depends on the risk factors concerning the population (Stabile $e t$ al. 1994). One out of every 100 pregnant women is ectopic with the most common site being within a fallopian tube (Walker et al. 2007). Morbidity and Mortality of ectopic pregnancy in the first trimester remains the mainly maternal mortality and morbidity (Grimes.1994, Airede. 2005, Okunlola. 2006). Maternal deaths caused by ruptured account up to 6\% and 31.9 cases of deaths per 100,000 has been reported in ectopic pregnancies related to assisted reproductive technology while mortality rate has decreased (Barnhart. 2009, Perkins. 2011). From 1:2000 to 1:18,000 maternal rate of mortality and morbidity occurred in cervical ectopic pregnant women (Yankowitz et al. 1990). Because the early diagnosis and treatment before rupture the incidence decreased to 0.5 cases of deaths per 1000 pregnancies (Chang et al., 2003). Cytokines, antiinflammatory, and Th-2 showed to be predominated in maternal-fetal interface of normal pregnancies (Wegmann. 1993, Mor. 2003). Any disorder between anti-inflammatory and pro-inflammatory cytokines balance effected on implantation(Formby et al. 1995) Cytokines important for facilitating of immune modulation in safely continuous of early stages of pregnancy by switching the type 2 responses(Chaouat et al. 2004). During the early implantation, the chemokines and Cytokines play important roles and increase trophoblast receptors expression (Hanna. 2003, Hannan.2006, Hannan. 2008). Cytokines can effect changes in cell numbers or structure of placenta and transport function of nutrient through blastocyst gene expression (Kwong. 2000, Sjöblom. 2005). Pre-implantation mechanism in the uterus established by the role of IL-6 family (Van Mourik et al. 2009). Pro-inflammatory TNF, IL-6 play important roles in the implantation process and detected in the maternal-fetal interface (Jabbour et al. 2009) Th1 produce tumor necrosis factor $\alpha$, IFN- $\alpha$ and interleukin 2 which promote cellular immune responses while Th2 produce IL-4, IL-5, IL-9, IL-10 and IL-13 which promote humoral responses (Mosmann. 1986, Veenstra. 2003).

\section{The Interleukin-1ra}

IL-1 agonistic and antagonistic were implicated in the implantation of embryonic and they evoke target cells to induce signal responses (Dower.1986, Mizel. 1989) Expression IL-1ra during follicular phase in Human endometrium show to be more than in luteal phase (Huang et al. 2006). IL-1ra suggested in prevention implantation mechanism of the embryo by the direct effect on microvillus endometrial of the mouse but this mechanism remains unclear (Simón et al. 1998). 


\section{Interleukin2}

IL-2 produced primarily by $\mathrm{CD}^{+} \mathrm{T}$ cells following their activation by antigen (Rubin et al. 1985). IL-2 have an abortogenic effect (Tezabwala et al. 1989).

\section{Interleukin 6}

IL-6 is produced by monocytes, macrophages, fibroblasts, endothelial cells, vascular smooth muscle cells and endometrial epithelial-stromal cells and by several endocrine glands, including the pituitary and the pancreas (Laird et al. 1993). Interleukin 6 has an important role in early implantation through a regulation production of ovarian steroid and in folliculogenesis (Machelon. 1994, Orsi. 2008). It also modulates secretion of other cytokines, promotes T-cell activation and B-cell differentiation and inhibits the growth of various human cell lines (Nothnick et al. 2001).

\section{Interleukin 8}

They produced from different cells type of including monocytes, Endothelial cells and fibroblasts (Yoshimura, 1987, Larsen, 1989, Strieter, 1989) are an inflammatory cytokine found in patients with endometriosis, particularly in the mild but most active stages of the disease (Ryan. 1995, Gazvani. 1998). The molecule mediates neutrophil migration, activation and induces the expression of leukocyte adhesion molecules (Baggiolini, 1989. Koch, 1992). Promotes endometrial stromal cell proliferation (Arici et al., 1998).

\section{Tumor Necrosis Factor $\alpha$}

TNF $\alpha$ is pro-inflammatory cytokine which activates signaling pathways for cell survival, apoptosis, inflammatory responses and cellular differentiation, It is mainly secreted by macrophages, lymphoid cells, mast cells, fibroblasts and can induce cell death of certain tumor cell lines (Kawasaki et al. 2002). Activated macrophages and Secreted TNF- $\alpha$ play a critical role in the pathogenesis of endometriosis and the systemic manifestations of the disease (Braun et al. 2002).

\section{Interferon $\alpha$}

INF $\alpha$ play important role in implantation, stabilize uterine in most mammals and affected the expression of many genes (Spencer. 2006, Spencer. 2008). It can also exert the induction of apoptosis and suppression of cellular growth (Rizza et al. 2010).

\section{MATERIALS AND METHODS}

The study was involved all reproductive age females were admiration from a Department of Obstetrics and Gynecology in Bent Al Huda Hospital in Iraq- ThiQar governorate during period from all patients data were recorded, Age, gravidity, gestational age, clinical presenting features, and ectopic risk factors (pelvic inflammatory disease, smoking, treatment of infertility, used an intrauterine contraceptive device, previous history of tubal surgery, pelvic surgery and previous ectopic). A Peak level of $\beta$-HCG, transvaginal-ultrasonographic In this study 90 cases from controls and patients groups 50 of them with pregnant women in the first trimester and 40 cases of ectopic pregnancy, Their ages were between (15-45) years and referred to the Gynecology Department from April 2016 to August 2016. Women with Ectopic pregnancy were diagnosed by measurement peak level of serum hCG concentrations, pelvic sonography and/or transvaginal ultrasonography. Patients groups were submitted full reports regarding their medical status history physical examination, laboratory tests, signs and symptoms of pelvic pain and/or amenorrhea. However, patients with recurrent 
miscarriage, Hydatidi form mole, and ovarian cancer were excluded. Verbal consents of all participants were taken.

\section{Collection of Sera}

A total of $5 \mathrm{ml}$ of blood was drawn from controls and patients groups.

Blood samples were centrifuged at 3000 r. p. $\mathrm{m}$ and sera were stored at $-20 \mathrm{C}^{\circ}$ was obtained from all the women for (, IL-6, IL-8, IL4, TNF, INF, IL1RA assay).

\section{Evaluation Level of Cytokines}

Enzyme-linked technology (kits of Immunosorbent assay) provided by Biobase biotechnology company was used to detect the level of certain cytokines in a blood sample of both groups.

\section{Statistical Analysis}

The data were analyzed using description statistic (mean and standard deviation) independent sample t test the level significant was set at $\mathrm{p}<0.05$ SPSS (Statistical Packing for Social Sciences) version 20.

\section{RESULTS}

\section{Age Group of Women Included in the Study}

Women with ectopic pregnancy included in the current study were fifty. They were classified according to their age group as shown in Table 1.

The highest percentage was (42\%) within the age (25-34 years), followed b (35-45 years) which was shown to be $38 \%$. Age group between (15-24 years) showed the lowest percentage (20\%).

\section{Table 1: Frequency of the Ectopic Pregnancy Group According to their Age Group}

\begin{tabular}{|c|c|c|}
\hline Age Group & Frequency & Percent (\%) \\
\hline $15-24$ & 10 & $20 \%$ \\
\hline $25-34$ & 21 & $42 \%$ \\
\hline $35-45$ & 19 & $38 \%$ \\
\hline Total & 50 & $100 \%$ \\
\hline
\end{tabular}

Classification of ectopic pregnancy according to the risk factor which is noted in 23 out of50 patients with ectopic pregnancy. The highest percentage was showed in those with a pelvic inflammatory disease which was $43.5 \%$ followed by Intrauterine contraceptive device was $17.3 \%$ while the smoking was the lowest percentage $4.3 \%$.

Table 2: Frequency of Ectopic Pregnancy Groups According to their Risk Factors

\begin{tabular}{|c|c|c|}
\hline Risk Factor & \multicolumn{2}{|c|}{ Frequency Percent } \\
\hline Pelvic inflammatory disease & 10 & $43.5 \%$ \\
\hline Intrauterine contraceptive device & 4 & $17.3 \%$ \\
\hline Previous histories of ectopic pregnancy & 3 & $13 \%$ \\
\hline Tubal surgery & 2 & $8.6 \%$ \\
\hline Assisted conceptively & 3 & $13 \%$ \\
\hline Smoking & 1 & $4.3 \%$ \\
\hline Total & 23 & 100 \\
\hline
\end{tabular}




\section{Mean Serum Levels of IL6, IL8, IL2, IL1RA, TNF $\alpha$, INF $\alpha$ in Controls and Patients Group}

The mean levels of serum cytokines IL6, IL8, IL1RAb, TNF, INF IL2 were measured in patients groups and control groups. IL6, IL8, IL1RAb, TNF, INF were higher in patients group with serum level (23.2508 pg/ml), (76.9892 $\mathrm{pg} / \mathrm{ml}),(9.3375 \mathrm{ng} / \mathrm{ml}),(31.5328 \mathrm{pg} / \mathrm{ml}),(24.7813 \mathrm{pg} / \mathrm{ml})$ respectively than control groups. The differences between patients and control groups were statistically significant (p-value $<0.00$ ) serum level of IL2 showed lower than patients $(2.2582 \mathrm{ng} / \mathrm{ml})$ the difference between patients and control was statistically not significant.

Table 3: Mean \pm SD Serum Levels of IL1RA, IL2, IL6, IL8, TNFa and INFa for Patients and Controls

\begin{tabular}{|l|c|c|c|c|c|c|c|}
\hline & No & IL1RA ng/ml & IL2 ng/ml & IL6 Pg/ml & IL8 Pg/ml & TNF $\alpha$ Pg/ml & INF $\alpha$ Pg/ml \\
\hline Patients & 50 & $9.3375 \pm 3.260$ & $2.2582 \pm 1.224$ & $23.2508 \pm 7.18$ & $76.9892 \pm 19.8$ & $31.5328 \pm 10.22$ & $24.7813 \pm 7.60$ \\
\hline Controls & 40 & $2.1151 \pm 1.16$ & $4.9923 \pm 1.59$ & $9.0025 \pm 2.74$ & $26.5498 \pm 11.85$ & $9.5346 \pm 10.22$ & $8.2140 \pm 2.68$ \\
\hline P value & & 0.00 & $>0.05$ & 0.000 & 0.000 & 0.000 & 0.000 \\
\hline
\end{tabular}

Mean Concentration Level of IL1ra for Ectopic Pregnancy and Controls Group

The mean level of IL1ra among ectopic pregnancy was $9.3375 \mathrm{ng} / \mathrm{ml}$, while the controls showed a level of 2.1151 $\mathrm{ng} / \mathrm{ml}$. The difference was highly significant (p-value 0.00$)$.

Table 4: Mean \pm SDIL1ra Concentration Level in Serum for Ectopic Pregnancy and Control Group

\begin{tabular}{|l|c|c|c|}
\hline IL1ra Concentration & No & Mean Concentration & p. Value \\
\hline Patient & 50 & $9.3375 \pm 3.260 \mathrm{ng} / \mathrm{ml}$ & 0.000 \\
\hline Control & 40 & $2.1151 \pm 1.16 \mathrm{ng} / \mathrm{ml}$ & \\
\hline
\end{tabular}

Mean Concentration Level of Serum IL 2 in the Serum of Patients and Controls Group

The mean level of serum IL 2 in patients was $2.2582 \mathrm{ng} / \mathrm{ml}$, while the control group was $4.9923 \mathrm{ng} / \mathrm{ml}$, these differences was insignificant ( $\mathrm{p}$-value $>0.05$ ).

Table 5: Mean \pm SD Concentration Level of IL2 in Serum for

Ectopic Pregnancy and Controls Group

\begin{tabular}{|l|c|c|c|}
\hline IL 2 Concentration. & No & Mean Concentration & p. Value \\
\hline Patients & 50 & $2.2582 \pm 1.224 \mathrm{ng} / \mathrm{ml}$ & $>0.05$ \\
\hline Controls & 40 & $4.9923 \pm 1.59 \mathrm{ng} / \mathrm{ml}$ & \\
\hline
\end{tabular}

Mean level of IL6 in the Serum for Ectopic

Pregnancy and Controls Group

The IL6 level in patients was $23.2508 \mathrm{pg} / \mathrm{ml}$, while the group of control showed $9.0025 \mathrm{pg} / \mathrm{ml}$. The differences were highly significant (p-value 0.00).

Table 6: Mean \pm SD Concentration level of Serum IL6 for Ectopic Pregnancy and Control Group

\begin{tabular}{|l|c|c|c|}
\hline IL 6 Concentration & No & Mean Concentration & p. Value \\
\hline Patients & 50 & $23.2508 \pm 7.18 \mathrm{Pg} / \mathrm{ml}$ & 0.000 \\
\hline Controls & 40 & $9.0025 \pm 2.74 \mathrm{Pg} / \mathrm{ml}$ & \\
\hline
\end{tabular}


The Mean Concentration Level of Serum IL8 for Ectopic Pregnancy and Controls Group

The mean level of IL8 in patients was $76.9892 \mathrm{pg} / \mathrm{ml}$, while the controls were $26.5498 \mathrm{pg} / \mathrm{ml}$. this differences showed highly significant (p-value 0.00 ).

Table 7: Mean \pm SD Concentration IL8 in the Serum of Ectopic Pregnancy and Controls Group

\begin{tabular}{|l|c|c|c|}
\hline IL8 Concentration & No & Mean Concentration & p. Value \\
\hline Patients & 50 & $76.9892 \pm 19.8 \mathrm{Pg} / \mathrm{ml}$ & 0.000 \\
\hline Controls & 40 & $26.5498 \pm 11.85 \mathrm{Pg} / \mathrm{ml}$ & \\
\hline
\end{tabular}

Mean Concentration of Serum TNFa for Ectopic Pregnancy and Controls Group

The mean concentration level of serum TNF $\alpha$ were $31.5328 \mathrm{pg} / \mathrm{ml}$, while the controls were $9.5346 \mathrm{pg} / \mathrm{ml}$. the differences were highly significant (p-value 0.00).

Table 8: Mean \pm SD Concentration of TNFa in Serum of Ectopic Pregnancy and Controls Group

TNF $\alpha$ Concentration. No|Mean Concentration $\mathbf{p .}$ Value

\begin{tabular}{|l|l|l|l|}
\hline Patients & 50 & $31.5328 \pm 10.22 \mathrm{Pg} / \mathrm{ml}$ & 0.000 \\
\hline
\end{tabular}

\begin{tabular}{|l|l|l|l|l|}
\hline Controls & 40 & $9.5346 \pm 10.22 \mathrm{Pg} / \mathrm{ml}$ & \\
\hline
\end{tabular}

Mean Concentration of the Serum INFa for Ectopic Pregnancy and Controls Group

The mean level of INF $\alpha$ in patients was $31.5328 \mathrm{pg} / \mathrm{ml}$, while the controls showed $9.5346 \mathrm{pg} / \mathrm{ml}$. The differences were highly significant (p-value 0.00).

Table 9: Mean \pm SD Concentration Level of INF $\alpha$ in Serum of Ectopic Pregnancy and Controls Group

\begin{tabular}{|l|c|c|c|}
\hline INF $\alpha$ Concentration & No & Mean Concentration & p. Value \\
\hline Patients & 50 & $24.7813 \pm 7.60 \mathrm{Pg} / \mathrm{ml}$ & 0.000 \\
\hline Controls & 40 & $8.2140 \pm 2.68 \mathrm{Pg} / \mathrm{ml}$ & \\
\hline
\end{tabular}

Table 10: Mean Concentration of Cytokines for Different Age Groups

\begin{tabular}{|c|c|c|c|c|c|c|}
\hline AGE GROUPS & IL1RA ng/ml & IL2 ng/ml & IL6 Pg/ml & IL8 Pg/ml & TNF $\alpha$ Pg/ml INF $\boldsymbol{~ P g / m l ~}$ \\
\hline $15-24$ yrs & $8.358 \pm 2.72$ & $1.44 \pm 1.30$ & $27.021 \pm 7.628$ & $80.76 \pm 17.33$ & $31.84 \pm 7.365$ & $23.65 \pm 6.94$ \\
\hline $25-34$ yrs & $9.162 \pm 2.731$ & $2.240 \pm 1.212$ & $23.35 \pm 6.364$ & $82.912 \pm 15.21$ & $36.09 \pm 9.405$ & $25.84 \pm 7.96$ \\
\hline $35-45$ yrs & $10.91 \pm 3.08$ & $2.26 \pm 0.932$ & $22.925 \pm 5.225$ & $77.27 \pm 19.69$ & $28.71 \pm 7.842$ & $26.147 \pm 5.50$ \\
\hline
\end{tabular}

\section{DISCUSSIONS}

Ectopic pregnancy is until a public health problem facing coupling expecting a child. Research has opened the probability of immune response to such pregnancy complications with special emphasis on the effects of pro-inflammatory and anti-inflammatory cytokines on the success or failure of pregnancy

\section{Demographic Property}

In the present study serum concentrations of IL-6, IL-8, IL1RA, interferon alpha and TNF $\alpha$ are higher in women with ectopic pregnancy while IL2 was lower than the control group. In comparison with the values of the cytokines with a first-trimester pregnancy. 
Case-controls study sought to determination the relative between up and down regulation of the cytokines of ectopic pregnancy as for as age groups are concerned. Women with age of 25-34 years showed a higher rate of ectopic pregnancy, this is in agreement with Opoku et al. (2013) which is possibly due to high reproductive activity

\section{Interleukin 1RA}

The mean level of serum Interleukin 1RA among ectopic pregnant women was highly elevated and there is statistical significant this finding was in agreement with that reported by Lekovic et al. (2013) in the United States. IL-1 play important role in regulation implantation of the embryo (Simon et al. 1995). IL-1RA, on the other hand, acts as a competitive inhibitor by binding to the IL-1 receptor without recruiting the IL-1 receptor-associated protein to the complex, therefore not inducing any intracellular signaling response (Arend et al. 1991). The blockade of IL-1 receptors by antagonists during the period before implantation results in inhibition and prevention of embryonic implantation. (Simon et al. 1994). A recent study reported failure implantation of the blastocyst and suggested inhibition implantation of the embryo in pregnant mice when injected with IL1ra (Simon et al.1994).

\section{Interleukin 2}

The mean concentration level of serum Interleukin 2 among ectopic pregnant women showed low than controls groups ,no statistically significant and this finding was in agreement with reported by Soriano et al. (2003) in France. In contrast to MacLean et al (1991). Who that finding a rise in IL-2 receptor levels in ectopic pregnancy. IL-2 indicates activation of the immune system, and thus monitoring of IL-2 receptor levels may lead to a more accurate prediction of the outcome of the pregnancy (MacLean et al. 1991). During pregnancy, inflammatory factors secretion by natural killer cells, and HLA-Class II molecules secretion promote by T-cells that lead to rejection of embryo, natural killer cells and T cells activated by IL-2 (Fu et al. 2007).

\section{Interleukin 6}

The mean levels of Th2 cytokineIL6 for ectopic pregnancy were high than controls groups and show association significant. This finding was in agreement with findings reported by two studies (Soriano. 2003, Farquhar. 2005). Increased levels of IL-6 in amniotic fluid were associated with membrane rupture of premature and infection of intrauterine (Fukuda et al. 2002). IL-6 signaling may be important for transporting embryo, therefore any abnormal levels of IL-6 alter tubal transport (Shao R et al. 2009). Interleukin-6 (IL-6) has embryotoxic effected and inhibits implantation of the blastocyst (Jacobs. 1992, Hill JA. 1992) IL-6 has anti-inflammatory effects and leading to induce of HCG from trophoblast, which promotes secretion of progesterone (Hill et al. 1992). A recent study reported reduces the tubal ciliary activity of epithelial when treated withIL-6 in vitro and restores ciliary activity when used anti-IL-6 (Papathanasiou et al. 2008). However, it can be stated that Th2 cytokines might be associated with successful pregnancy.

\section{Interleukin 8}

The mean levels of Th2 cytokine IL8 for ectopic pregnancy were higher than the controls groups and show statistically significance and this finding was in agreement with that reported by Soriano et al. (2003). Interleukin 8 induced by inflammation in the fallopian tube, may provide signals to the embryo and promote tubal implantation (Shao $e t$ al. 2007). IL-8 are inflammatory cytokines and its highly elevated in the Fallopian tube infection by Chlamydia (Mpiga et al. 2006) and also in ectopic implantation (Balasubramaniam et al. 2012). Implantation of the embryo in uterus stimulation the local inflammatory response in a similar way as leukocytes accumulates at inflammatory sites of implantation 
(Dominguez et al., 2005). Another study found the potential utility of IL-8 in diagnosing an ectopic pregnancy, as compared to normal intrauterine pregnancy and miscarriage (Rajendiran et al. 2016). In contrast to, Rausch et al (2012). Who observed lower values of IL-8 and TNF- $\alpha$ in women with ectopic pregnancy.

\section{Tumor Necrosis Factor Alpha}

The result of the current study showed the mean level of tumor necrosis factor alpha was higher in patients with ectopic pregnancy compared to control group the difference were highly statistically significant so that finding was not in agreement with Rausch et al. (2012). Therefore the current study were agreement with the role of affected tumor necrosis factor is harmful to pregnancy because they cause embryonic inhibition and in development fet al (Chaouat. 1990, Haimovici. 1991). And in agreement with reported by (Soriano et al. 2003). TNF- $\alpha$ has been proposed to act as a mediator of detrimental stimuli inducing embryonic death by activating apoptosis of trophoblast cells, whereas IFN- $\gamma$ augments TNF-mediated death of trophoblasts (Robaye.1991, Yui J. 1994). Several studies have shown elevated serum TNF-a levels in patients with pregnancies problem compared with normal pregnancies (Vassiliadis. 1998, Gucer. 2001). A recent study has proposed a possible protective role of TNF- $\alpha$ at the fetoplacental unit with an implication in mechanisms preventing the occurrence of malformed offspring (Toder et al. 2003). Pathophysiological effects failure in implantation and endometriosis showed to be associated with increased expression of TNFa (Cao WG et al. 2005). TNF was shown to increase hCG secretion of JAR cells, whereas the cytokine reduced hCG secretion from term placenta ciliated sloughing of tubal epithelial mucosa cells associated with up-regulation in TNF- $\alpha$ (McGee et al. 1999). One study found that higher IL-8, IL-6, and TNF- $\alpha$ were present in women with EP when compared to pregnant with normal pregnancy and, miscarriage though only IL (Rausch et al. 2011).

\section{Interferon Alpha}

The mean level of serum INF $\alpha$ in patients was $31.5328 \mathrm{pg} / \mathrm{ml}$, while the controls were high level $9.5346 \mathrm{pg} / \mathrm{ml}$. To the best of my knowledge, there are no published studies between the relationship of INF $\alpha$ with ectopic pregnancy

\section{CONCLUSIONS}

- The present study revealed a significant indicator between cytokines levels and ectopic pregnancy.

- The cytokines were detected in patients with ectopic pregnancy and control group in first trimester.

- There is a significant associations IL-1ra, IL-6, IL-8, TNF $\alpha$ and INF $\alpha$ levels of ectopic pregnancy

- There is no significant association between IL-2 level of and ectopic pregnancy.

- The higher concentration of cytokines (IL 1RA, IL 2, INF $\alpha$ )was found among age group (35- 45 years), while TNF $\alpha$ and IL8 highly in age group (25 - 34 year) and IL 6 concentration mean was in age group (15 - 24 years).

- Although a direct causal relationship between cytokines levels of ectopic pregnancy has not been determined, differences, in cytokines activity have been reported for normal pregnant women and those of ectopic pregnancy.

- Mean concentration of interleukin 1 $\mathrm{ra}(9.3375 \pm 3.260 \mathrm{ng} / \mathrm{ml})$ were higher in study group than control group $(2.1151 \pm 1.16 \mathrm{ng} / \mathrm{ml})$. 
- Mean concentration of interleukin $2(2.2582 \pm 1.224 \mathrm{ng} / \mathrm{ml})$ were lower in study group than control group $(4.9923 \pm 1.59 \mathrm{ng} / \mathrm{ml})$.

- Mean concentration of interleukin $6(23.2508 \pm 7.18 \mathrm{Pg} / \mathrm{ml})$ were higher in study group than control group $(9.0025 \pm 2.74 \mathrm{Pg} / \mathrm{ml})$.

- Mean concentration of interleukin $8(76.9892 \pm 19.8 \mathrm{Pg} / \mathrm{ml})$ were higher in study group than control group $(26.5498 \pm 11.85 \mathrm{Pg} / \mathrm{ml})$.

- Mean concentration of tumor necrosis factor $\alpha(31.5328 \pm 10.22 \mathrm{Pg} / \mathrm{ml})$ were higher in study group than control group $(9.5346 \pm 10.22 \mathrm{Pg} / \mathrm{ml})$.

- Mean concentration of interferon $\alpha(24.7813 \pm 7.60 \mathrm{Pg} / \mathrm{ml})$ were higher in study group than control group $(8.2140 \pm 2.68 \mathrm{Pg} / \mathrm{ml})$.

\section{REFERENCES}

1. Abdul IF. Ectopic pregnancy in Ilorin, Nigeria. International Journal of Gynecology \& Obstetrics. 1999 Aug 1;66(2):179-80

2. Airede LR, Ekele BA. Ectopic pregnancy in Sokoto, Northern Nigeria. Malawi Medical Journal. 2005;17(1):14-6.

3. Arend WP. Interleukin 1 receptor antagonist. A new member of the interleukin 1 family. The Journal of clinical investigation. 1991 Nov 1;88(5):1445-51.

4. Arici A, Seli E, Senturk LM, Gutierrez LS, Oral E, Taylor HS. Interleukin-8 in the human endometrium. The Journal of Clinical Endocrinology \& Metabolism. 1998 May 1;83(5):1783-7.

5. Baggiolini M, Walz A, Kunkel SL. Neutrophil-activating peptide-1/interleukin 8, a novel cytokine that activates neutrophils. Journal of Clinical Investigation. 1989 Oct;84(4):1045.

6. Balasubramaniam ES, Van Noorden S, El-Bahrawy M. The expression of interleukin (IL)-6, IL-8, and their receptors in fallopian tubes with ectopic tubal gestation. Fertility and Sterility. 2012 Oct 31;98(4):898-904.

7. $\quad$ Barnhart KT. Ectopic pregnancy. New England Journal of Medicine. 2009 Jul 23;361(4):379-87.

8. Braun DP, Ding J, Dmowski WP. Peritoneal fluid-mediated enhancement of eutopic and ectopic endometrial cell proliferation is dependent on tumor necrosis factor- $\alpha$ in women with endometriosis. Fertility and Sterility. 2002 Oct 31;78(4):727-32

9. Cao WG, Morin M, Sengers V, Metz C, Roger T, Maheux R, Akoum A. Tumour necrosis factor- $\alpha$ up-regulates macrophage migration inhibitory factor expression in endometrial stromal cells via the nuclear transcription factor NF- $\kappa B$. Human Reproduction. 2005 Oct 6;21(2):421-8.

10. Chang J, Elam-Evans LD, Berg CJ, Herndon J, Flowers L, Seed KA, Syverson CJ. Pregnancy-related mortality surveillanceUnited States, 1991-1999. MMWR SurveillSumm. 2003 Feb 21;52(2):1-8.

11. Chaouat $G$, Ledée-Bataille N, Dubanchet S, Zourbas S, Sandra O, Martal J. TH1/TH2 paradigm in pregnancy: paradigm lost?. International archives of allergy and immunology. 2004;134(2):93-119.

12. Chaouat G, Menu E, Clark DA, Dy M, Minkowski M, Wegmann TG. Control of fet al survival in CBA× DBA/2 mice by lymphokine therapy. Journal of Reproduction and Fertility. $1990 \mathrm{Jul}$ 1;89(2):447-58.

13. Dominguez F, Yanez-Mo M, Sanchez-Madrid F, Simon C. Embryonic implantation and leukocyte transendothelial migration: different processes with similar players?. The FASEB journal. 2005 Jul 1;19(9):1056-60. 
14. Dower SK, Kronheim SR, Hopp TP, Cantrell M, Deeley M, Gillis S, Henney CS, Urdal DL. The cell surface receptors for interleukin-1 $\alpha$ and interleukin-1 $\beta$ are identical. Nature. 1986 Nov;324(6094):266.

15. Farquhar CM. Ectopic pregnancy. Lancet. 2005;366:583-591.

16. Formby B. Immunologic response in pregnancy. Its role in endocrine disorders of pregnancy and influence on the course of maternal autoimmune diseases. Endocrinology and Metabolism Clinics of North America. 1995 Mar;24(1):187-205.

17. Fu W, Shi B. Correlation of T lymphocyte subsets and serum IL-2, IL-10 with spontaneous abortion. Jiangsu Medical Journal. $2007 ; 33(4): 328$

18. Fkuda H, Masuzaki H, Ishimaru T. Interleukin $\square 6$ and interleukin $\square 1$ receptor antagonist in amniotic fluid and cord blood in patients with pre $\square$ term, premature rupture of the membranes. International Journal of Gynecology \& Obstetrics. 2002 May $1 ; 77(2): 123-9$.

19. Gazvani MR, Christmas S, Quenby S, Kirwan J, Johnson PM, Kingsland CR. Peritoneal fluid concentrations of iterleukin-8 in women with endometriosis: relationship to stage of disease. Human Reproduction (Oxford, England). 1998 Jul 1;13(7):195761 .

20. Grimes DA. The morbidity and mortality of pregnancy: still risky business. American Journal of Obstetrics and Gynecology. 1994 May 1;170(5):1489-94.

21. Gücer F, Balkanli-Kaplan P, Yüksel M, Sayin NC, Yüce MA, Yardim T. Maternal serum levels of tumor necrosis factor- $\alpha$ ad interleukin-2 receptor in threatened abortion: a comparison with normal and pathologic pregnancies. Fertility and Sterility. 2001 Oct 31;76(4):707-11.

22. Haimovici F, Hill JA, Anderson DJ. The effects of soluble products of activated lymphocytes and macrophages on blastocyst implantation events in vitro. Biology of Reproduction. 1991 Jan 1;44(1):69-75.

23. Hanna J, Wald O, Goldman-Wohl D, Prus D, Markel G, Gazit R, Katz G, Haimov-Kochman R, Fujii N, Yagel S, Peled A. CXCL12 expression by invasive trophoblasts induces the specific migration of CD16-human natural killer cells. Blood. 2003 Sep 1;102(5):1569-77.

24. Hannan NJ, Jones RL, White CA, Salamonsen LA. The chemokines, CX3CL1, CCL14, and CCLA, promote human trophoblast migration at the feto-maternal interface. Biology of Reproduction. 2006 May 1;74(5):896-904.

25. Hannan NJ, Salamonsen LA. CX3CL1 and CCL14 regulate extracellular matrix and adhesion molecules in the trophoblast: potential roles in human embryo implantation. Biology of Reproduction. $2008 \mathrm{Jul}$ 1;79(1):58-65.

26. HILL JA. Cytokines considered critical in pregnancy. American Journal of Reproductive Immunology. 1992 Oct $12 ; 28(3 \square 4): 123-6$.

27. Huang H. The cytokine network during embryo implantation. Chang Gung medical journal. 2006 Jan;29(1):25.

28. Jabbour HN, Sales KJ, Catalano RD, Norman JE. Inflammatory pathways in female reproductive health and disease. Reproduction. 2009 Dec 1;138(6):903-19.

29. Jacobs AL, Sehgal PB, Julian JO, Carson DD. Secretion and hormonal regulation of interleukin-6 production by mouse uterine stromal and polarized epithelial cells cultured in vitro. Endocrinology. 1992 Sep 1;131(3):1037-46.

30. Kawasaki H, Onuki R, Suyama E, Taira K. Identification of genes that function in the TNF- $\alpha$-mediated apoptotic pathway using randomized hybrid ribozyme libraries. Nature Biotechnology. 2002 Apr 1;20(4):376-80. 
31. Koch AE, Polverini PJ, Kunkel SL, Harlow LA, DiPietro LA, Elner VM, Elner SG, Strieter RM. Interleukin-8 as a macrophage-derived mediator of angiogenesis. Science. 1992 Dec 11;258(5089):1798-801.

32. Kwong WY, Wild AE, Roberts $P$, Willis AC, Fleming TP. Maternal undernutrition during the preimplantation period of rat development causes blastocyst abnormalities and programming of postnatal hypertension. Development. 2000 Oct 1;127(19):4195-202.

33. Laird SM, Li TC, Bolton AE. The production of placental protein 14 and interleukin 6 by human endometrial cells in culture. Human Reproduction. 1993 Jun 1;8(6):793-8.

34. Larsen CG, Anderson AO, Oppenheim JJ, Matsushima K. Production of interleukin-8 by human dermal fibroblasts and keratinocytes in response to interleukin-1 or tumour necrosis factor. Immunology. 1989 Sep;68(1):31.

35. Lekovic J, Doulaveris G, Orfanelli T, Shulman B, Witkin SS, Spandorfer SD. Interleukin-1 $\beta$ and Interleukin-1 receptor antagonist serum levels one week after embryo transfer may predict ectopic pregnancy in IVF cycles. Fertility and Sterility. 2013 Sep 1;100(3):S138.

36. Machelon V, Emilie D, Lefevre A, Nome F, Durand-Gasselin I, Testart J. Interleukin-6 biosynthesis in human preovulatory follicles: some of its potential roles at ovulation. The Journal of Clinical Endocrinology \& Metabolism. 1994 Aug;79(2):63342.

37. MacLean MA, Wilson R, Thomson JA, Krishnamurthy S, Walker JJ. Changes in immunologic parameters in normal pregnancy and spontaneous abortion. American Journal of Obstetrics and Gynecology. 1991 Oct 1;165(4):890-5.

38. Mcgee ZA, Jensen RL, Clemens CM, Taylor-Robinson D, Johnson AP, Gregg CR. Gonococcal Infection of Human Fallopian Tube Mucosa in Organ Culture: Relationship of Mucosal Tissue TNF $\square$ a Concentration to Sloughing of Ciliated Cells. Sexually Transmitted Diseases. 1999 Mar 1;26(3):160-5.

39. Mizel SB. The interleukins. FASEB Journal 1989;3:2379-88.

40. Mor G, Abrahams VM. Potential role of macrophages as immunoregulators of pregnancy. Reproductive Biology and Endocrinology. 2003 Dec 2;1(1):119.

41. Mosmann TR, Cherwinski H, Bond MW, Giedlin MA, Coffman RL. Two types of murine helper T cell clone. I. Definition according to profiles of lymphokine activities and secreted proteins. The Journal of Immunology. 1986 Apr 1;136(7):2348-57.

42. Mpiga P, Mansour S, Morisset R, Beaulieu R, Ravaoarinoro M. Sustained Interleukin $\square 6$ and Interleukin $\square 8$ Expression Following Infection with Chlamydia trachomatis Serovar L2 in a HeLa/THP $\square 1$ Cell Co $\square$ culture Model. Scandinavian Journal of Immunology. 2006 Mar 1;63(3):199-207.

43. Nothnick WB. Treating endometriosis as an autoimmune disease. FertilSteril 2001;76:223-31.

44. Okunlola MA, Adesina OA, Adekunle AO. Repeat ipsilateral ectopic gestation: a series of 3 cases. African Journal of Medicine and Medical Sciences. 2006 Jun;35(2):173-5.

45. Opoku BK, Nguah SB, Azanu W. Ectopic pregnancy: Are fair-colored women at increased risk?. Gynecology. 2013 Apr $1 ; 1(1): 1$.

46. Orsi NM, Tribe RM. Cytokine networks and the regulation of uterine function in pregnancy and parturition. Journal of Neuroendocrinology. 2008 Apr 1;20(4):462-9.

47. Papathanasiou A, Djahanbakhch O, Saridogan E, Lyons RA. The effect of interleukin-6 on ciliary beat frequency in the human fallopian tube. Fertility and Sterility. 2008 Aug 31;90(2):391-4. 
48. Rajendiran S, Senthil Kumar GP, Nimesh A, Dhiman P, Shivaraman K, Soundararaghavan S. Diagnostic significance of IL-6 and IL-8 in tubal ectopic pregnancy. Journal of Obstetrics and Gynaecology. 2016 Oct 2;36(7):909-11.

49. Rausch ME, Barnhart K. Serum biomarkers for detecting ectopic pregnancy. Clinical Obstetrics and Gynecology. 2012 Jun;55(2):418.

50. Rausch ME, Sammel MD, Takacs P, Chung K, Shaunik A, Barnhart KT. Development of a multiple marker test for ectopic pregnancy. Obstetrics \& Gynecology. 2011 Mar 1;117(3):573-82.

51. Rizza P, Moretti F, Belardelli F. Recent advances on the immunomodulatory effects of IFN- $\alpha$ : implications for cancer immunotherapy and autoimmunity. Autoimmunity. 2010 May 1;43(3):204-9.

52. Robaye B, Mosselmans R, Fiers W, Dumont JE, Galand P. Tumor necrosis factor induces apoptosis (programmed cell death) in normal endothelial cells in vitro. The American Journal of Pathology. 1991 Feb;138(2):447.

53. Rubin LA, Kurman CC, Fritz ME, Biddison WE, Boutin BE, Yarchoan RO, Nelson DL. Soluble interleukin 2 receptors are released from activated human lymphoid cells in vitro. The Journal of Immunology. 1985 Nov 1;135(5):3172-7.

54. Ryan IP, Tseng JF, Schriock ED, Khorram O, Landers DV, Taylor RN. Interleukin-8 concentrations are elevated in peritoneal fluid of women with endometriosis. Fertility and Sterility. 1995 Apr 30;63(4):929-32.

55. Shao R, Egecioglu E, Weijdegård B, Kopchick JJ, Fernandez-Rodriguez J, Andersson N, Billig H. Dynamic regulation of estrogen receptor- $\alpha$ isoform expression in the mouse fallopian tube: mechanistic insight into estrogen-dependent production and secretion of insulin-like growth factors. American Journal of Physiology-Endocrinology and Metabolism. 2007 Nov 1;293(5):E1430-42.

56. Shao R, Nutu M, Karlsson-Lindahl L, Benrick A, Weijdegård B, Lager S, Egecioglu E, Fernandez-Rodriguez, J, GemzellDanielsson K, Ohlsson C, Jansson JO, Billig H. Downregulation of cilia-localized Il-6R alpha by 17beta-estradiol in mouse and human fallopian tubes. Am J Physiol Cell Physiol. 2009;297:C140-C151

57. Simón C, Pellicer A, Polan ML. Interleukin-1 system crosstalk between embryo and endometrium in implantation. Human Reproduction. 1995 Dec 1;10(suppl_2):43-54.

58. Simón C, Valbuena D, Krüssel J, Bernal A, Murphy CR, Shaw T, Pellicer A, Polan ML. Interleukin-1 receptor antagonist prevents embryonic implantation by a direct effect on the endometrial epithelium. Fertility and Sterility. 1998 Nov 30;70(5):896-906.

59. Simón CA, Piquette GN, Frances A, el-Danasouri IM, Irwin JC, Polan ML. The effect of interleukin-1 beta (IL-1 beta) on the regulation of IL-1 receptor type I messenger ribonucleic acid and protein levels in cultured human endometrial stromal and glandular cells. The Journal of Clinical Endocrinology \& Metabolism. 1994 Mar;78(3):675-82.

60. Sjöblom C, Roberts CT, Wikland M, Robertson SA. Granulocyte-macrophage colony-stimulating factor alleviates adverse consequences of embryo culture on fet al growth trajectory and placental morphogenesis. Endocrinology. 2005 May 1;146(5):2142-53.

61. Soriano D, Hugol D, Quang NT, Darai E. Serum concentrations of interleukin-2R $(I L-2 R), I L-6, I L-8$, and tumor necrosis factor alpha in patients with ectopic pregnancy. Fertility and Sterility. 2003 Apr 30;79(4):975-80.

62. Spencer TE, Johnson GA, Bazer FW, Burghardt RC, Palmarini M. Pregnancy recognition and conceptus implantation in domestic ruminants: roles of progesterone, interferons and endogenous retroviruses. Reproduction, Fertility and Development. 2006 Dec 12;19(1):65-78. 
63. Spencer TE, Sandra O, Wolf E. Genes involved in conceptus-endometrial interactions in ruminants: insights from reductionism and thoughts on holistic approaches. Reproduction. 2008 Feb 1;135(2):165-79.

64. Stabile I, Grudzinskas JG. Ectopic pregnancy: what's new. Progress in Obstetrics and Gynaecology. 1994;11:281-305.

65. Strieter RM, Kunkel SL, Showell HJ, Remick DG, Phan SH, Ward PA, Marks RM. Endothelial cell gene expression of a neutrophil chemotactic factor by TNF-alpha, LPS, and IL-1 beta. Science. 1989 Mar 17;243(4897):1467-9.

66. Kadhim, H. N., Hashim, E. A., \& Abdulla, S. A. B. Comparative Study Of Gonadotropin-Releasing Hormone Receptor In Fallopian Tube By Immunohistochemistry Among Women With Ectopic Pregnancy, Hysterectomy And Tubal Ligation.

67. Tezabwala BU, Johnson PM, Rees RC. Inhibition of pregnancy viability in mice following IL-2 administration. Immunology. 1989 May;67(1):115.

68. Toder V, Fein A, Carp H, Torchinsky A. TNF- $\alpha$ in pregnancy loss and embryo maldevelopment: a mediator of detrimental stimuli or a protector of the fetoplacental unit?. Journal of assisted Reproduction and Genetics. 2003 Feb 1;20(2):73-81.

69. Van Mourik MS, Macklon NS, Heijnen CJ. Embryonic implantation: cytokines, adhesion molecules, and immune cells in establishing an implantation environment. Journal of Leukocyte Biology. 2009 Jan 1;85(1):4-19.

70. Vassiliadis S, Ranella A, Papadimitriou L, Makrygiannakis A, Athanassakis I. Serum levels of pro-and anti-inflammatory cytokines in non-pregnant women, during pregnancy, labour and abortion. Mediators of Inflammation. 1998;7(2):69-72.

71. Veenstra van Nieuwenhoven AL, Heineman MJ, Faas MM. The immunology of successful pregnancy. Human Reproduction Update. 2003 Jul 1;9(4):347-57.

72. Wegmann TG, Lin H, Guilbert L, Mosmann TR. Bidirectional cytokine interactions in the maternal-fet al relationship: is successful pregnancy a TH2 phenomenon?. Immunology today. 1993 Jul 1;14(7):353-6.

73. Yankowitz J, Leake J, Huggins G, Gazaway P, Gates E. Cervical ectopic pregnancy: review of the literature and report of a case treated by single-dose methotrexate therapy. Obstetrical \& Gynecological Survey. 1990 Jul 1;45(7):405-14.

74. Yoshimura T, Matsushima K, Oppenheim JJ, Leonard EJ. Neutrophil chemotactic factor produced by lipopolysaccharide (LPS)-stimulated human blood mononuclear leukocytes: partial characterization and separation from interleukin 1 (IL 1). The Journal of Immunology. 1987 Aug 1;139(3):788-93.

75. Yui J, Garcia-Lloret M, Wegmann TE, Guilbert LJ. Cytotoxicity of tumour necrosis factor-alpha and gamma-interferon against primary human placental trophoblasts. Placenta. 1994 Dec 1;15(8):819-35. 
